\title{
OLHARES SOBRE A DRENAGEM EM BRASÍLIA: EXPANSÃO URBANA E INFRAESTRUTURA SOCIOECOLÓGICA NA SERRINHA DO PARANOÁ, DF
}

\author{
A GLANCE OVER URBAN DRAINAGE IN BRASÍLIA: URBAN EXPANSION AND SOCIOECOLOGICAL \\ INFRASTRUCTURE IN "SERRINHA DO PARANOÁ", DF
}

\author{
CÁTIA DOS SANTOS CONSERVA | UNB \\ LIZA MARIA SOUZA DE ANDRADE, Dra.|UNB \\ DANIEL RICHARD SANT'ANA, Dr. |UNB \\ DANIELA JUNQUEIRA CARVALHO|UNB \\ MARIA ELISA LEITE COSTA, M.SC.|UNB \\ SÉRGIO KOIDE, Dr. | UNB
}

\begin{abstract}
RESUMO
O presente artigo tem o objetivo de analisar como os processos de expansão urbana impactam a sociedade e o meio ambiente, investigando interferências na drenagem de águas pluviais. Tem como estudo de caso o Projeto de expansão urbana do SHTQ - Setor Habitacional Taquari, também conhecido como Serrinha do Paranoá, em Brasília. Tem motivação justificada pela lacuna na literatura no que diz respeito a relacionar aspectos de crescimento urbano com o escoamento superficial. A análise foi feita com emprego da abordagem metodológica da Socioecologia, aquela que analisa criticamente as interações entre o homem e recursos naturais. Os resultados indicam aumento de até $165 \%$ na vazão máxima pelo cálculo simplificado, e de 98 \% por meio de simulação hidrológica do modelo SWMM, caso a urbanização seja feita nos moldes do projeto elaborado pela Administração Pública. Os resultados demonstraram que o uso das soluções de baixo impacto como biovaletas representa diminuição da vazão máxima de escoamento, com ganhos para a produção das águas.
\end{abstract}

PALAVRAS CHAVE: Drenagem; Expansão Urbana; Socioecologia

\begin{abstract}
The scope of this paper is to analyse the ways urban expansion processes impacts society and the environment, emphasizing rainfall drainage. The aim of this study is the Urban Expansion Project for the Taquari Housing Sector, SHTQ, also known as "Serrinha do Paranoá", in Brasilia. The reason for the study is to fulfill a gap regarding aspects of urban growth and run off. The analysis consists of the socioecological methodology, the one that critically analyzes

the interactions between humans and natural resources. The investigation consists of the socioecological methodology, which recognizes the interactions between humans and natural resources. The results indicate growth up to $165 \%$ in the maximum run off output rate by simplified calculations, and of $98 \%$ through hidrological SWMM model simulation, if the urbanizing process follows the project elaborated by the public administration. The results showed that the use of low impact solutions, as infiltration swales, represents a decrease in run off, with gains for the production of water.
\end{abstract}

KEY WORDS: Drainage; Urban Expansion; Socioecology 


\section{INTRODUÇÃO}

A relação entre projetos de expansão urbana em áreas ambientalmente sensíveis e a proteção do meio ambiente, com recorte na questão da drenagem em tempos de crise hídrica é o tema do presente artigo. Percebe-se, na literatura, uma lacuna a respeito de estudos que tenham foco na análise crítica da relação entre formas predatórias de expansão do território e o aumento no escoamento superficial, na vazão máxima de lançamento, em um contexto de crise hídrica.

As causas da crise hídrica, no caso de Brasília, estão relacionadas ao agravamento do desmatamento do cerrado pelo agronegócio e pela urbanização com crescimento populacional contínuo sem o aporte concomitante das obras estruturantes.

As modificações no solo afetam diretamente as funções de uma bacia hidrográfica. Superfícies impermeáveis e solos compactados filtram menos água, o que aumenta o escoamento superficial e diminui a infiltração da água no solo (ANDRADE, 2014). Na medida em que a ocupação urbana tende a ocupar áreas sensíveis ambientalmente, com remoção da cobertura vegetal nativa e aumento da impermeabilização do solo, a urbanização gera impactos negativos ao ciclo hidrológico natural.

É neste contexto que em Brasília assiste-se à promoção de vários loteamentos idealizados pela Administração Pública em áreas consideradas ambientalmente sensíveis. Dentre eles, o projeto de expansão do SHTQ, área considerada de elevada sensibilidade ambiental por tratar-se de área de vegetação preservada, divisora de bacias, produtora de água para o Lago Paranoá, o qual já está em processo de assoreamento e configura, em um contexto de crise hídrica, manancial de abastecimento para mais de 600 mil pessoas (ANDRADE et al, 2018). No presente artigo, a Serrinha do Paranoá será estudada no Trecho 2 da Etapa 1, alvo de projeto elaborado na década de 90 pela TERRACAP - Agência de Desenvolvimento do Distrito Federal, como expansão do Trecho 1, já consolidado.

A respeito deste projeto, a comunidade da Serrinha do Paranoá vislumbra problemas relativos a impactos ambientais pelo desmatamento e impermeabilização do solo, que poderão deteriorar a qualidade e a quantidade das águas produzidas para o Lago Paranoá (ANDRADE et al, 2018). Com essa preocupação a comunidade da Serrinha do Paranoá, em 2017, procurou o MPDFT Ministério Público do Distrito Federal e Territórios, o qual, juntamente com a sociedade e o Grupo de Pesquisa "Água e Ambiente Construído" da FAU/UnB - Faculdade de Arquitetura e Urbanismo da Universidade de Brasília, no âmbito do Projeto de Pesquisa "Brasília Sensível à Água" (GDF, 2018), organizou uma Audiência Pública intitulada "Escassez Hídrica no DF". Como resultado desta Audiência foi organizado o Seminário "O Lago Paranoá e a Crise Hídrica: Desafios do Planejamento Urbano para Brasília", em parceria entre o MPDFT, organizações da sociedade civil e a Universidade de Brasília, além de contribuições temáticas de vários setores do GDF - Governo do Distrito Federal. Tendo o Trecho 2 da Etapa 1 do SHTQ como estudo de caso, o Seminário demonstrou o agenciamento de eventos e atores para a gestão compartilhada da água na bacia hidrográfica do Lago Paranoá (ANDRADE et al, 2018).

A relevância dos resultados do Seminário motivou a emissão, pelo MPDFT, em 2017, do Termo de Recomendação 09/2017, no qual recomendou a suspensão da Licença de Instalação LI 059/2014 emitida para o Trecho 2 da Etapa 1 do SHTQ, bem como a adoção de modelos de desenho urbano que sejam sensíveis à água e considerem critérios de proteção ambiental que respeitem os limites da capacidade de suporte do Lago Paranoá (ANDRADE et al, 2018). A LI 059/2014 foi suspensa em novembro de 2017 e assim permanece até o momento da escrita do presente artigo. Considera-se que o estudo do caso do SHTQ se justifica pela possibilidade de oferecer uma contribuição crítica para as discussões sobre processos de expansão urbana, preservação ambiental e drenagem em ocupação urbana de áreas ambientalmente sensíveis.

\subsection{OBJETIVO}

O artigo tem como objetivo analisar a relação entre processos de projeto de expansão urbana e drenagem. A análise investiga impactos resultantes de projetos de drenagem elaborados com padrões de infraestrutura convencionais face ao desenho urbano sensível à água com técnicas da infraestrutura Socioecológica, seus impactos no escoamento superficial e na vazão máxima de lançamento.

\subsection{METODOLOGIA}

A análise pressupõe a água como eixo metodológico de pesquisa ao abordar aspectos da expansão urbana através dos impactos na drenagem de águas pluviais, tendo em vista o estudo dos projetos urbanístico e de drenagem elaborados pela Administração Pública para o SHTQ Trecho 2 Etapa 1. Tem como método de análise a Abordagem Socioecológica, aquela que identifica como a interação homem-meio ambiente está relacionada com 
os processos socioeconômicos, e as consequências de mudanças nos padrões de uso de recursos (BUSCHBACHER, 2014). A caracterização da área de estudo norteou a construção da base de dados para o cálculo simplificado da vazão máxima de lançamento com o Método Racional para três cenários, definidos de acordo com a Tabela 1, Figuras 1 a 3.

\begin{tabular}{|l|l|l|}
\hline \multicolumn{2}{|c|}{ Cenários } & \multicolumn{1}{c|}{ Descrição } \\
\hline $\mathbf{1}$ & Pré-desenvolvimento & $\begin{array}{l}\text { Vegetação Preservada e pouca } \\
\text { atividade antrópica. É o cenário atual } \\
\text { do Trecho 2 da Etapa 1 do SHTQ. }\end{array}$ \\
\hline $\mathbf{2}$ & Ocupação Urbana & $\begin{array}{l}\text { cupação urbana com projeto } \\
\text { nos moldes do projeto pro- } \\
\text { posto pela TERRACAP. }\end{array}$ \\
\hline $\mathbf{3}$ & $\begin{array}{l}\text { Ocupação urbana } \\
\text { + Infraestrutura } \\
\text { Socioecológica }\end{array}$ & $\begin{array}{l}\text { Ocupação urbana, porém com o } \\
\text { uso de biovaletas ao longo das vias } \\
\text { e curvas de nível nos moldes do } \\
\text { projeto conceitual do projeto "Brasília } \\
\text { Sensível à Água" (2018) da FAU/UnB. }\end{array}$ \\
\hline
\end{tabular}

Tabela 1: Cenários de Análise Trecho 2 da Etapa 1 do SHTQ.

Fonte: Os Autores, 2018.

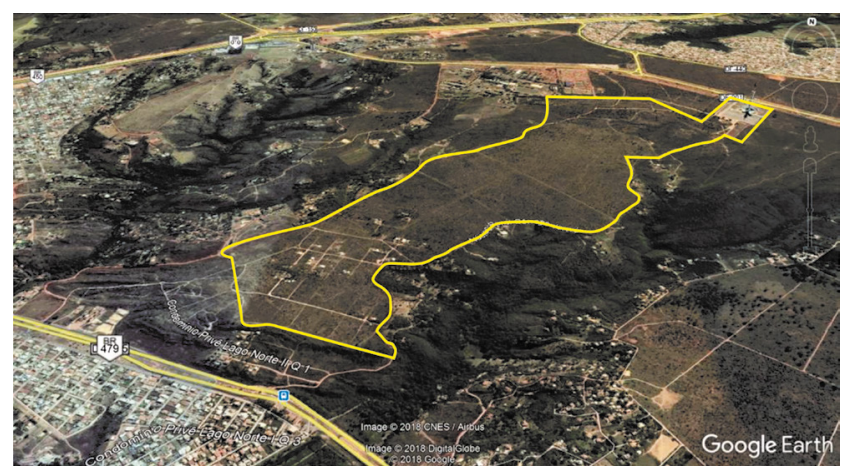

Figura 1: 0 Trecho 2 Etapa 1 do SHTQ em cenário pré-desenvolvimento. Fonte: Conserva, 2019, adaptado de Google Earth, 2018.

A Figura 2, relativa ao cenário 2, é um desenho conceitual baseado no projeto TERRACAP - MDE 019/2016 com sobreposição dos parâmetros da LUOS - Lei de Uso e Ocupação do Solo, Lei Complementar no 948, de 16 de janeiro de 2019.

A LUOS estabelece os critérios e os parâmetros de uso e ocupação do solo para lotes e projeções localizados na Macrozona Urbana do Distrito Federal. Compreende instrumento complementar das políticas de ordenamento territorial e de expansão e desenvolvimento urbano do Distrito Federal. Na Figura 3, o Trecho em cenário de ocupação urbana mais biovaletas em desenho conceitual elaborado pelo projeto "Brasília Sensível à Água" em atendimento a solicitação do MPDFT.

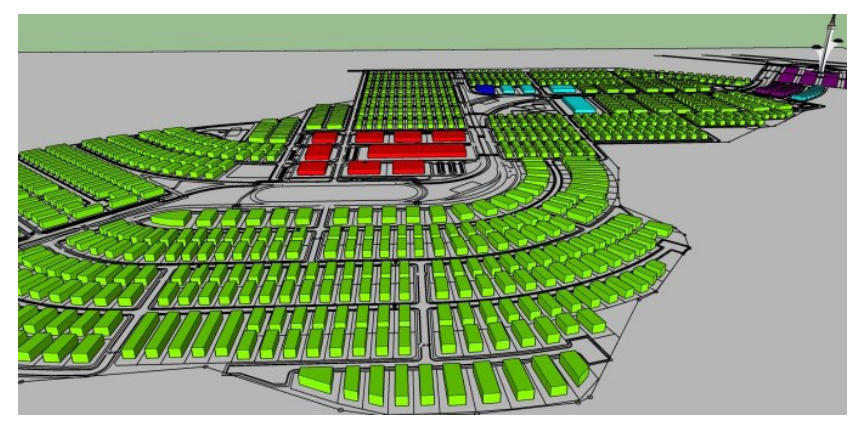

Figura 2: 0 Trecho 2 da Etapa 1 do SHTQ, cenário 2.. Fonte: Conserva, 2019, baseado em TERRACAP, MDE 019/2016

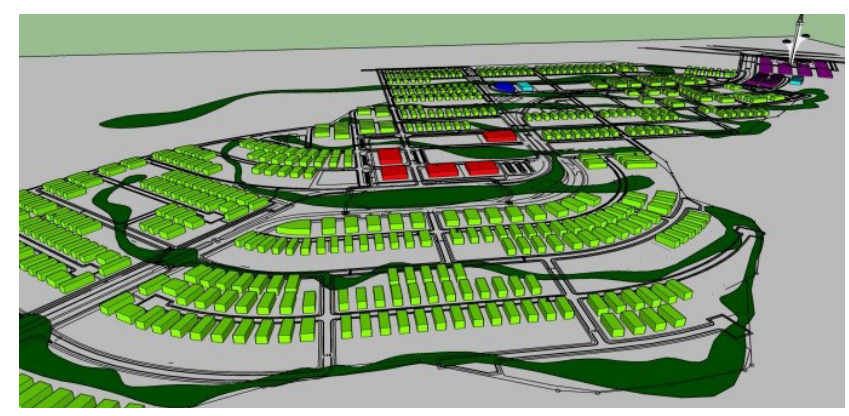

Figura 3: 0 Trecho 2 da Etapa 1 do SHTQ, cenário 3. Fonte: Brasília Sensível à Água, 2019

O Método Racional faz uso de uma simplificação para relacionar a vazão escoada com a intensidade da chuva precipitada sobre a área de drenagem, descontadas as perdas associadas com os demais processos do ciclo hidrológico (MIGUEZ et al, 2016). O Método Racional não considera o retardamento natural do escoamento e pressupõe chuva com intensidade constante e uniformemente distribuída na bacia hidrográfica em toda a sua duração.

Os resultados do cálculo da vazão máxima pelo método simplificado para os cenários 1 e 2 foram comparados aos resultados com a simulação do modelo SWMM "Storm Water Management Model", Modelo de Gestão de Drenagem Urbana, com método SCS, "Soil Conservations Service", para geração do escoamento superficial, feitos por Carvalho (2018). O SWMM, da EPA - “U.S. Environmental Protection Agency", Agência de Proteção Ambiental dos Estados Unidos, é um modelo que simula a quantidade do escoamento superficial, especialmente em áreas urbanas (ROSSMAN, 2010). Trata-se de um programa gratuito e de código aberto que trata variáveis hidrológicas, hidráulicas e de qualidade da água, criado para modelar sistemas de drenagem urbanos.

\section{EXPANSÃO URBANA E DRENAGEM}

A água, como elemento indispensável à vida humana, tem sido fator de relevância na localização e desenvolvimento 
das cidades, as quais se desenvolveram, em sua grande maioria, no entorno de corpos d'água.

Neste sentido, Benevolo (2011) exprime a cidade como uma criação histórica que teve início com eventos envolvidos na relação de proximidade com corpos d'água, a partir das possibilidades agrícolas em detrimento do nomadismo. Para ele a cidade cresce a partir das grandes mudanças na organização produtiva que transformaram a vida cotidiana do ser humano.

Benevolo (2001) e Miguez et al (2016) assumem que após a Revolução Industrial as atividades humanas passam a refletir grandes impactos ao meio ambiente natural. Após a transformação para um mundo eminentemente urbano, as cidades, densamente populosas, começaram a sofrer profundas alterações em seus processos de consumo dos recursos naturais como um todo.

Um sistema de drenagem é altamente influenciado pela urbanização (MIGUEZ et al, 2016). A urbanização causa o aumento do escoamento superficial e da vazão máxima, com diminuição da evapotranspiração e da formação das águas subterrâneas (ANDRADE, 2014). Sob o pretexto do higienismo, aquele no qual a ênfase está no rápido transporte das águas pluviais ao exutório através de redes e galerias, o planejamento urbano imaginou ser possível prescindir da cobertura vegetal.

Solos foram impermeabilizados, aumentando o escoamento superficial e linhas de drenagem naturais foram substituídas por galerias pluviais projetadas para conduzir as águas de forma rápida e invisível, expediente sinistro que transfere o volume indesejado de água para uma comunidade mais a jusante (PELLEGRINO et al, 2017). A urbanização gera impactos ambientais na medida em que a ocupação urbana tende a ocupar áreas sensíveis ambientalmente, acumulando degradações no ambiente natural.

Em Brasília, tal análise da relação ocupação do espaço urbano e impactos ambientais é emblemática. A drenagem urbana foi preocupação desde a concepção do Plano Piloto, em cujo relatório observa-se, após o traçado do " $X$ " no chão, um esboço de preocupação com a questão da drenagem: "Procurou-se depois a adaptação à topografia local, ao escoamento natural das águas." (CODEPLAN, 1991).

Não se esperava, porém, que Brasília fosse se expandindo para além do Plano Piloto por meio de grandes pressões para o parcelamento do solo para fins urbanos, cujos impactos nos sugerem uma desintegração e desconexão entre si e com os fluxos da natureza e das águas. Em Brasília, o crescimento não previsto culminou com um tipo de ocupação do território dentro e fora da Bacia do
Paranoá, sem o adequado provimento da infraestrutura adequada.

\subsection{Olhares sobre a Drenagem Urbana: Do Convencional ao Desenho Urbano Sensível à Água}

O sistema convencional de drenagem das águas pluviais possui como premissa de eficiência a promoção do rápido escoamento das águas das chuvas por redes subterrâneas a serem despejadas em rios e lagos (MIGUEZ et aç, 2016). A urbanização tradicional é baseada na infraestrutura cinza monofuncional em que os sistemas de drenagem objetivam escoar a água o mais rápido possível, interferindo e bloqueando as dinâmicas naturais.

Porém, se observarmos a natureza, vemos que a drenagem das águas das chuvas acontece primeiramente com a interceptação nas copas das árvores, infiltração no solo, depois com a detenção natural, evaporação e, por último, com o escoamento superficial (HERZOG, 2010). Assim, vemos funções ecológicas importantes para promover a infiltração das águas das chuvas, reduzindo o impacto das gotas que compactam o solo, contribuindo para prevenir erosão e assoreamento de corpos d'água, favorecendo a mitigação de impactos ambientais

Contrastando com o sistema convencional de coleta e transporte, Andrade (2014) aborda padrões de desenho urbano com novos olhares sobre a questão da água direcionada e infiltrada no solo em padrões projetados para reduzir o fluxo, assegurando a produção das águas para os aquíferos. Neste sentido, buscando imitar a natureza, é que a infraestrutura Socioecológica aborda uma forma de desenho urbano que tenha consonância com o fluxo das águas, vegetação abundante e técnicas tais como biovaletas, visando evitar ao máximo que a água da chuva se transforme em escoamento superficial, maior causador de erosões e assoreamentos.

Neste sentido, conceito importante é o do WSUD, "Water Sensitive Urban Design", o Desenho Urbano Sensível à Água, programa que enfatiza a influência das configurações urbanas sobre os fluxos de recursos naturais. Visa assegurar que o desenvolvimento urbano e a paisagem sejam cuidadosamente projetados, construídos e mantidos de forma a minimizar os impactos sobre o ciclo da água no contexto urbano (ANDRADE, 2014). O desenho urbano sensível à água aplica técnicas e princípios de design responsivo ao clima e à saúde ecológica das paisagens terrestres e aquática. Associa os fatores socioeconômicos ao desenho urbano, buscando atender aos princípios de sustentabilidade para os assentamentos urbanos. 
O conceito WSUD começou a ser usado em 1990 na Austrália (FLETCHER et al, 2015) com os objetivos de:

a) Manejar o balanço das águas, considerando as águas subterrâneas e o escoamento superficial;

b) Cuidar da qualidade das águas pelas vias da proteção da vegetação e minimização do transporte de poluentes;

c) Integrar o manejo das águas com a paisagem;

d) Manejo apropriado das águas de drenagem urbana para redução do escoamento superficial com minimização das áreas impermeabilizadas e soluções locais de infiltração;

e) Uso de tecnologias ecológicas para minimização da infraestrutura convencional de drenagem.

Dentre os conceitos de desenho urbano em sintonia com a natureza, este trabalho vai fazer uso das estratéguas LID - "Low Impact Development", desenho de baixo impacto. O conceito de estratégias LID diz respeito a minimizar os impactos das águas urbanas através do uso do conceito de desenhar com a natureza (FLETCHER et al, 2015). Na minimização de tais impactos, um dos principais expoentes das estratégias LID está em proteger áreas de recarga de aquíferos com foco na redução do escoamento superficial pela urbanização. As estratégias LID têm sido amplamente utilizadas no modelo SWMM como dados de entrada a fim de quantificar os benefícios do uso destas técnicas no desenvolvimento urbano principalmente na redução dos volumes referentes ao escoamento superficial.

Alguns padrões LID em Infra Estrutura Socioecológica na visão de Andrade (2014) para drenagem urbana:

Visão Holística e Transdisciplinar dos fluxos da água, pois quando as políticas, planos do territórios e zoneamentos urbano, rural, manejo e recursos hídricos são feitos de forma integrada formando uma teia de relações entre a paisagem e a comunidade, todo o fluxo da água é favorecido, uma vez que é estudado em todas as suas variantes e especificidades (ANDRADE, 2014);

Quando a topografia possui elevada inclinação, a simples retirada da vegetação aumenta a velocidade do escoamento das águas pluviais, provocando erosões e assoreamentos nos corpos d'água, além de prejudicar as terras cultiváveis. (ANDRADE, 2014)

Técnicas de bioengenharia para contenção de muros, taludes, encostas e margens de cursos d'água, usando materiais inertes (pedras, troncos finos e flexíveis, bambu, muros de gabião, sacos com substrato, pneus) e vegetação (ANDRADE, 2014)

Canais de Infiltração em forma de valas de nível ou valas construídas como faixas de umidade ao longo das curvas de nível do terreno, em forma de longas trincheiras rasas, que funcionam ao longo do contorno da paisagem para barrar o escoamento superficial, favorecer a agricultura e recuperar áreas degradas. (ANDRADE, 2014)

Traçado das Vias em formatos que influenciem positivamente os fluxos das águas na Bacia Hidrográfica, garantam a manutenção da permeabilidade do solo e a hidrologia. A seleção de alternativa de desenho com vias curvilíneas e grandes macroparcelas pode resultar em redução de $26 \%$ no total de áreas impermeáveis. (ANDRADE, 2014)

Biovaletas ou Valas com vegetação e faixas de proteção. Integradas às características da paisagem em parques, jardins, projetos de ruas, podem ser usadas para transmitir o excesso de fluxo no transbordamento da água represada. Garantir a densidade suficiente para os diferentes tipos de vegetação a fim de proporcionarem uma boa filtração. (ANDRADE, 2014)

Filtração das águas pluviais por meio de Jardins de Chuvas, em camadas médias de areia com vegetação. Em seguida a água é recolhida por tubos perfurados para o curso da água fluir para reutilização. A vegetação previne a erosão do meio filtrante, carrega os nutrientes e a água, além de gerar a quebra contínua da estrutura pelo crescimento da planta, evitando o entupimento do sistema e fornecendo biofilmes. Em áreas mais íngremes, barragens de verificação são necessárias para reduzir o fluxo de velocidades. Para inclinação mais suaves é importante garantir uma drenagem adequada para evitar alagamentos. (ANDRADE, 2014)

Cova de Árvore de jardins de chuva em interação com o ambiente construído para incorporar o tratamento de águas pluviais em ruas cujo escoamento desvia o fluxo para as covas das árvores. Constituem buracos que circundas as árvores para filtrar o escoamento das águas de chuvas por meio da vegetação. Um tubo perfurado é incorporado ao projeto para fornecer a subdrenagem para os canais de recepção e alagamento. (ANDRADE, 2014)

Pavimento Poroso. A instalação de pavimentos porosos proporciona maior absorção de água para o solo subjacente e diminui o escoamento da água poluída que é arrastada para os rios. Ocorre aumento da recarga de águas subterrâneas e melhora da qualidade da água. (ANDRADE, 2014)

Trincheiras de Infiltração em áreas industriais e áreas mais densas, também ao longo de ruas e avenidas para infiltração de água das áreas urbanas pavimentadas. Estruturas lineares pouco profundas que funcionam 
como filtro e permitem o armazenamento e a infiltração da água no solo. (ANDRADE, 2014)

Praças pequenas de Bairro para Infiltração. As praças pequenas são utilizadas para infiltração das águas pluviais a partir de padrões espaciais como biorretenções, pequenas lagoas, zonas úmidas ou trincheiras de infiltração. (ANDRADE, 2014)

Traçado do Terreno e Paisagismo. Investigar os padrões de drenagem existentes no local logo nos primeiros riscos de projeto no terreno, estudando fluxos esperados, solo, topografia, precipitação, vegetação. Uso de plantas nativas e telas de proteção para filtrar as sujeiras que são carreadas com os cursos d'água, direcionando o escoamento das águas pluviais das vias, calçados e gramados para áreas de produção de alimentos e jardins. (ANDRADE, 2014)

Tetos Verdes. Os telhados verdes, além de reter boa quantidade das águas das chuvas, proporcionam melhoria na eficiência energética, na qualidade do ar (retenção de até $85 \%$ da poeira), na redução do barulho, na estética e no aumento da vida útil do telhado e na diminuição do volume das águas que iam para as galerias. (ANDRADE, 2014)

A Infraestrutura Socioecológica, em um conceito construído com a visão sistêmica, com as LID e o WSUD, aponta para a necessidade de que o controle de velocidade das águas seja feito, em primeiro lugar e principalmente, no local onde caem as chuvas, ou seja no interior dos lotes, praças, calçadas, vias e espaços públicos. Também na maneira como eles são desenhados, de forma que o desenho urbano favoreça a infiltração das águas o máximo possível e que somente após essa infiltração recorra-se a medidas de escoamento.

Os conceitos baseados nas LID e no WSUD foram recentemente chancelados pela ONU por meio do conceito NbS, "Nature Based Solutions", as Soluções Baseadas na Natureza propõem que o mundo deve trabalhar com a natureza, não contra ela. Reconhecem a importância do manejo sustentável das águas para a meta 6 da Agenda 2030 para o Desenvolvimento Sustentável. Abrange soluções inspiradas e apoiadas pela imitação de processos naturais para melhorar a gestão da água (WWDR, 2018). As NbS apoiam a economia circular em contraste com a economia linear, promovendo maior produtividade dos recursos, reduzindo resíduos e evitando contaminação.

Com o estudo da infraestrutura na abordagem da Socioecologia pretende-se abordar novos olhares sobre a água urbana que considere a visão metropolitana do território, o direito à cidade e a resiliência do meio natural

\section{ESTUDO DE CASO: O PROJETO DE EXPAN- SÃO URBANA DA SERRINHA DO PARANOÁ, TRECHO 2 ETAPA 1}

O SHTQ, também conhecido como Serrinha do Paranoá, é área de expansão urbana prevista no documento Brasília Revisitada (1986) como a Asa Nova Norte, Figura 4. Lembrando que o documento Brasília Revisitada enfatiza a necessidade da proteção do meio ambiente quando da ocupação urbana: "Convém ainda destinar parte da Asa Nova Norte a parcelamento em lotes individuais, aproveitando a topografia, respeitada a proteção arborizada dos córregos e nascentes" (BRASILIA REVISITADA, 1986).

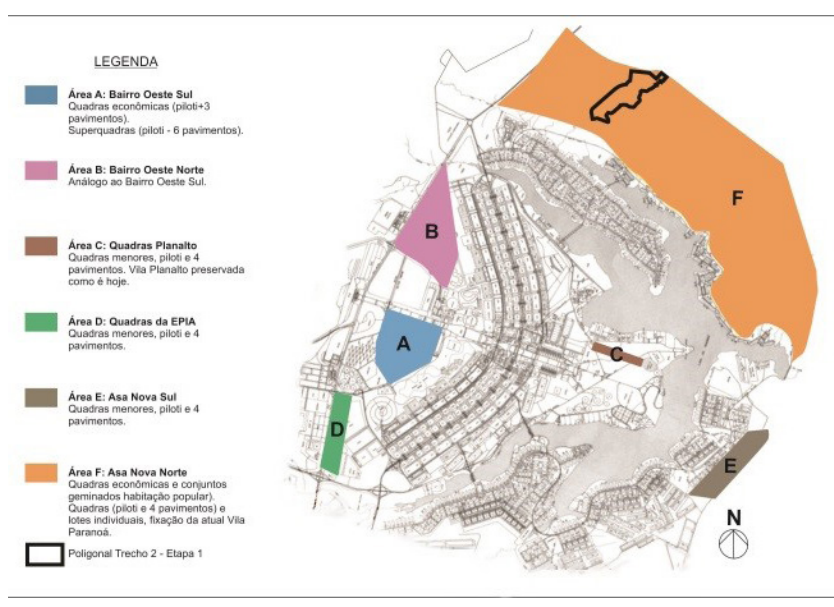

Figura 4: A poligonal do Trecho 2 da Etapa 1 do SHTQ na Asa Nova Norte do documento Brasília Revisitada.

Fonte: Conserva, 2019, adaptado de Brasília Revisitada, 1986.

Localizado entre as sub-bacias do Torto e do Lago Paranoá, o trecho faz parte do Grupo Hidrológico A com latossolos vermelho e amarelo (SEGETH, 2018). Trata-se de uma área de alta sensibilidade ambiental devido à existência de uma série de nascentes e cursos d'água que alimentam o Lago Paranoá, vegetação preservada e trechos com declividade acentuada.

A área destinada à implantação do Loteamento Trecho 02 do SHTQ pertence à RA XVIII, Lago Norte, com 223 ha. É desmembrada de área maior da Fazenda Brejo ou Torto, de propriedade da TERRACAP (MDE 019/2016), Figura 5.

O Trecho 2 da Etapa 1 do SHTQ foi definido pela TERRACAP como expansão urbana do Trecho 1 já consolidado, Figura 6.

Está localizado na saída Norte de Brasília, mais especificamente na Unidade de Planejamento Territorial Centro Adjacente 1 (PDOT, 2009), conforme Figura 7. 


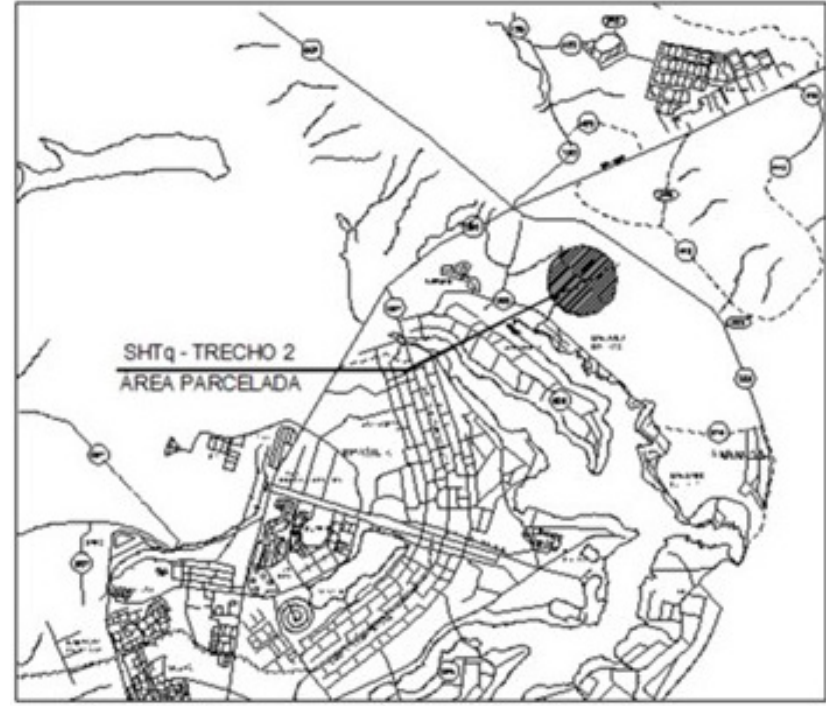

Figura 5: Localização da área do Trecho 2 da Etapa 1 do SHTQ. Fonte: TERRACAP, MDE 019/2016

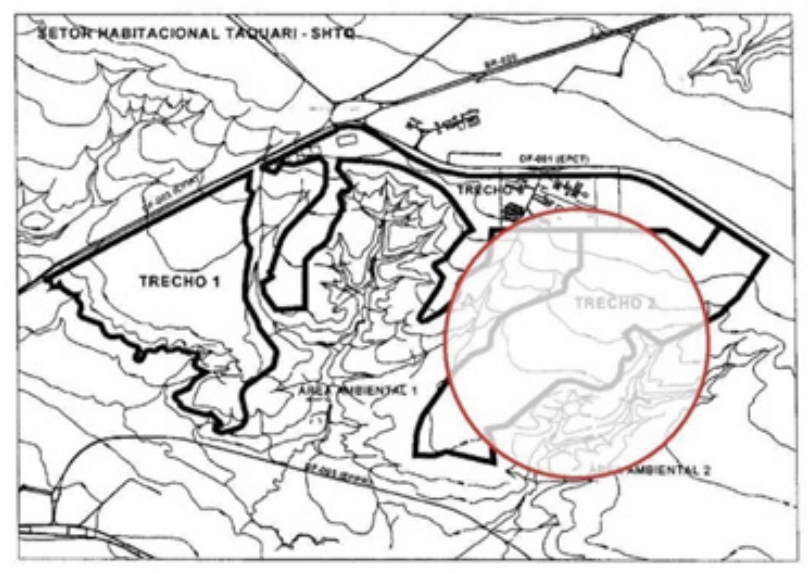

Figura 6: 0 Trecho 2 da Etapa 1 do SHTQ. Fonte: TERRACAP, MDE 111/1999

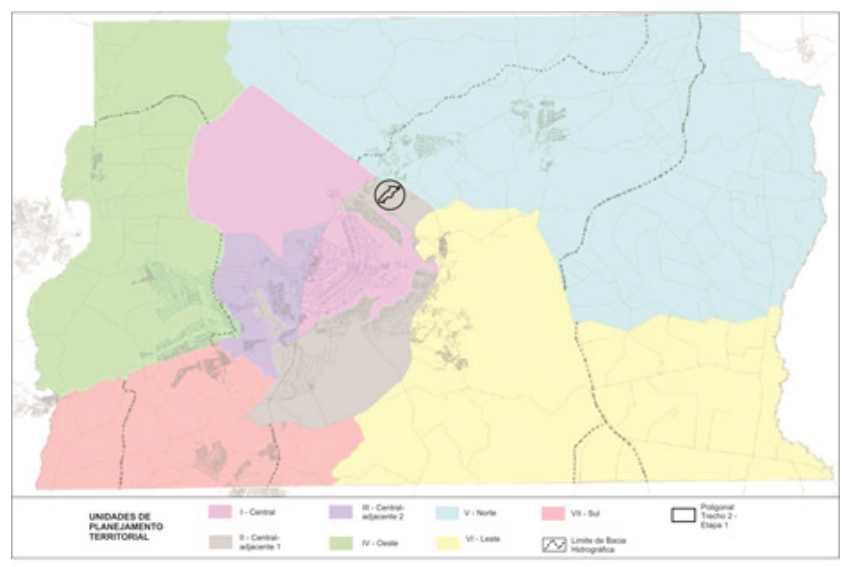

Figura 7: A poligonal do Trecho 2 da Etapa 1 do SHTQ na Unidade de Planejamento Territorial Centro Adjacente 1.

Fonte: Conserva, 2019,adaptado de PD0T/2009.
A região está inserida na Área de Proteção Ambiental - APA do Lago Paranoá como Subzona de Ocupação Especial do Taquari, Figura 8.

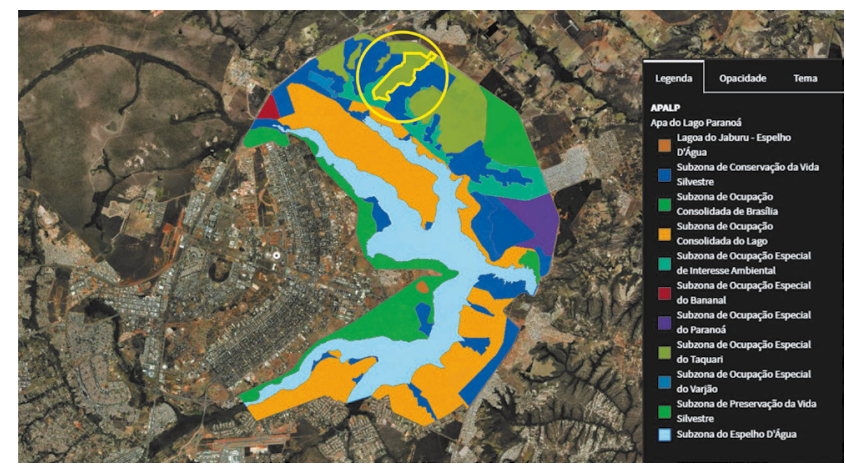

Figura 8: A poligonal do Trecho 2 da Etapa 1 do SHTQ na APA do Lago Paranoá. Fonte: Conserva, 2019, adaptado de SEGETH, 2018.

Também faz parte da APA do Planalto Central como Zona de Uso Sustentável, Figura 9. Ressalta-se que em Áreas de Proteção Ambiental é permitido um certo grau de ocupação humana, porém respeitando o objetivo básico de proteger a diversidade biológica conforme especifica a Lei 9.985, de 18 de julho de 2000, a Lei do SNUC - Sistema Nacional de Unidades de Conservação da Natureza.

A inserção do empreendimento nas APAs do Lago Paranoá e do Planalto Central constitui importante questão de sensibilidade ambiental da área objeto de expansão urbana do SHTQ. Como partes de regiões de APA, apesar de permitido um certo grau de ocupação, suas alternativas de desenvolvimento devem estar associadas a iniciativas relacionadas à qualidade ambiental, respeito às aptidões e à cultura local, pesquisa científica, extensão ambiental e turismo rural.

Em áreas de expansão urbana periféricas como é o caso da região da Serrinha do Paranoá, as ocupações devem ser direcionadas primordialmente para uso rural, mantendo suas funções ecológicas, de forma a permitir a passagem de pequenos animais, pólen, sementes, através da manutenção dos corredores ecológicos.

Do ponto mais a montante, na borda da DF 001 até a DF 005, a poligonal do Trecho 2 da Etapa 1 do SHTQ apresenta desnível de $188 \mathrm{~m}$ (GOOGLE EARTH, 2008). A Figura 10 apresenta as curvas de nível de 5 em $5 \mathrm{~m}$, demonstrando a declividade considerável do terreno ao sul da poligonal, fator de sensibilidade ambiental da região.

A declividade acentuada do terreno é fator que afeta a infiltração das águas no solo. Declividades acentuadas tendem a dificultar o contato da água com o solo em 


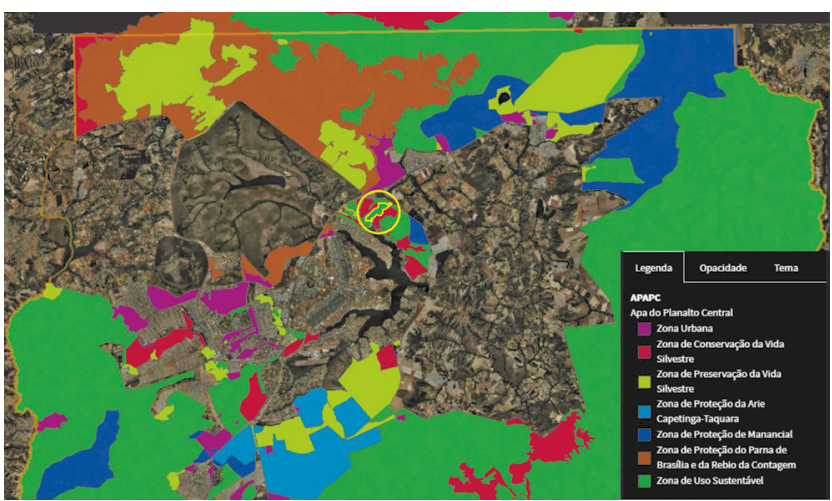

Figura 9: A poligonal do Trecho 2 da Etapa 1 do SHTQ na APA do Planalto Central. Fonte: Conserva, 2019, adaptado de SEGETH, 2018

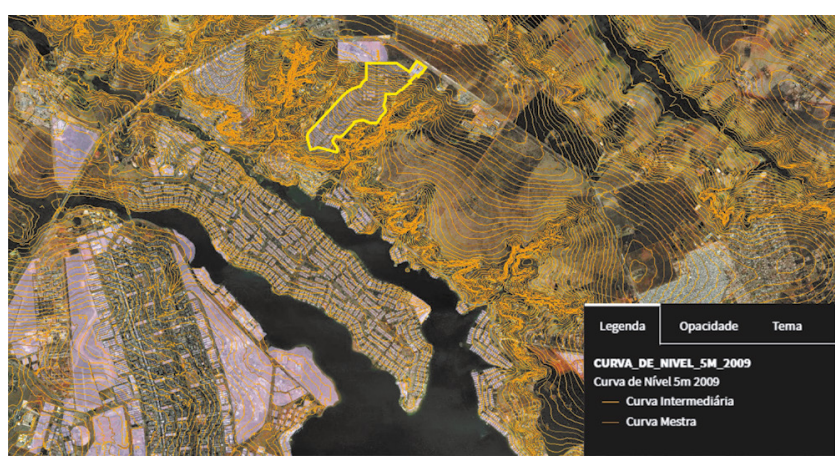

Figura 10 - A Poligonal do Trecho 2 da Etapa 1 do SHTQ no Mapa de Curvas de Nível 5 em $5 \mathrm{~m}$. Fonte: Conserva, 2019, adaptado de SEGETH, 2018

condições naturais (KOIDE, 2008). Esta dificuldade de contato faz com que as águas escoem superficialmente com mais velocidade e vazão.

A Figura 11 mostra a poligonal do Trecho 2 da Etapa 1 do SHTQ sobre o mapa de vegetação do GEOPORTAL (SEGETH, 2018), demonstrando a existência de uma vegetação de campo ainda preservada, com cerrado típico nas regiões das galerias.

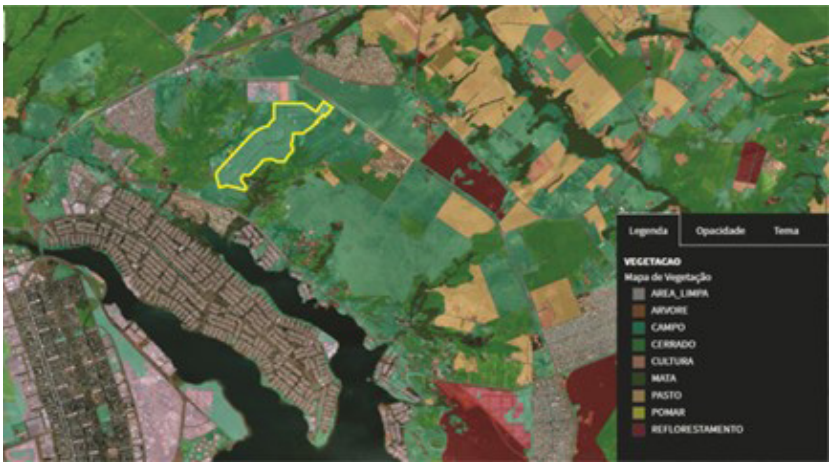

Figura 11: A poligonal do Trecho 2 da Etapa 1 do SHTQ no Mapa de Vegetação de Brasília. Fonte: Conserva, 2019, adaptado de SEGETH, 2018.

De acordo com Koide (2008), a cobertura vegetal é dos fatores mais importantes para a manutenção da capacidade de infiltração de um solo, pois evita a compactação da superfície, quebra a estrutura dos solos e pode dar abrigo a animais que favoreçam o aparecimento de macroporos.

Reforçando ainda mais a noção da sensibilidade ambiental da região, a Figura 6 demonstra uma série de nascentes e cursos d'água que alimentam o Lago Paranoá. A indicação amarela no mapa da Figura 12 representa as nascentes mapeadas pela comunidade com mapa fornecido pela Administração Regional do Lago Norte. Em azul, aquelas indicadas no GEOPORTAL (SEGETH, 2018).

$\mathrm{Na}$ análise da Figura 12, vemos que a quantidade de nascentes mapeadas pela comunidade é bem maior do que aquelas constantes no GEOPORTAL (SEGETH, 2018). São 97 nascentes mapeadas pela comunidade e 17 nascentes mapeadas pelo GEOPORTAL (SEGETH, 2018).

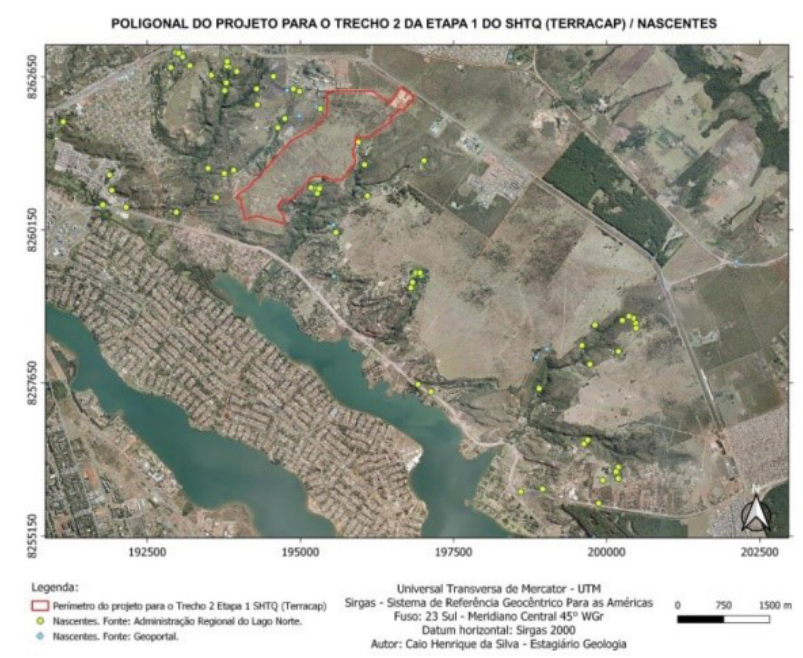

Figura 12: A poligonal do Trecho 2 da Etapa 1 do SHTQ no mapa de Nascentes em SIRGAS 2000 Fonte: Caio Henrique da Silva, 2019, estagiário sob a supervisão dos Autores. Adaptado de SEGETH, 2018 e Administração do Lago Norte, 2018.

A Figura 13 mostra a sobreposição da poligonal de projeto do Trecho 2 Etapa 1, SHTQ, com o mapa de Unidades Hidrográficas do DF, "shapefile" obtida do GEOPORTAL (SEGETH, 2018). Nele vemos que a região localiza-se sobre uma linha divisora de bacias, as sub-bacias do Ribeirão do Torto e do Lago Paranoá, além de fazer divisa com a sub-bacia do Ribeirão Sobradinho.

A Figura 14 mostra a sobreposição da poligonal de projeto do Trecho 2 Etapa 1, SHTQ, com o mapa de Áreas de APP - Áreas de Preservação Permanente. O mapa foi elaborado em ambiente SIG, nuvens de pontos LIDAR, precisão altimétrica de $15 \mathrm{~cm}$. Nele vemos que há cinco pontos de interferência da poligonal com as Áreas de Preservação Permanente. 


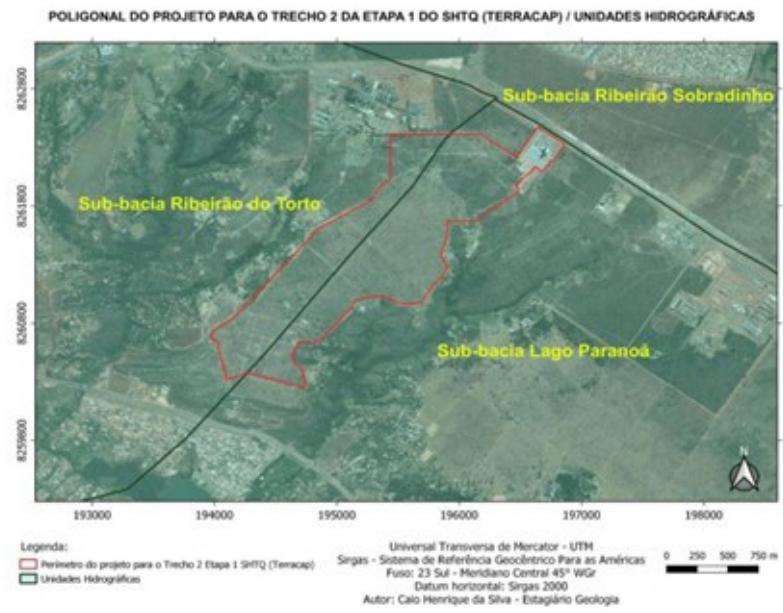

Figura 13: A poligonal do Trecho 2 da Etapa 1 sobre o mapa de Unidades Hidrográficas do DF, em SIRGAS 2000 .

Fonte: Caio Henrique da Silva, estagiário sob supervisão dos Autores, 2019

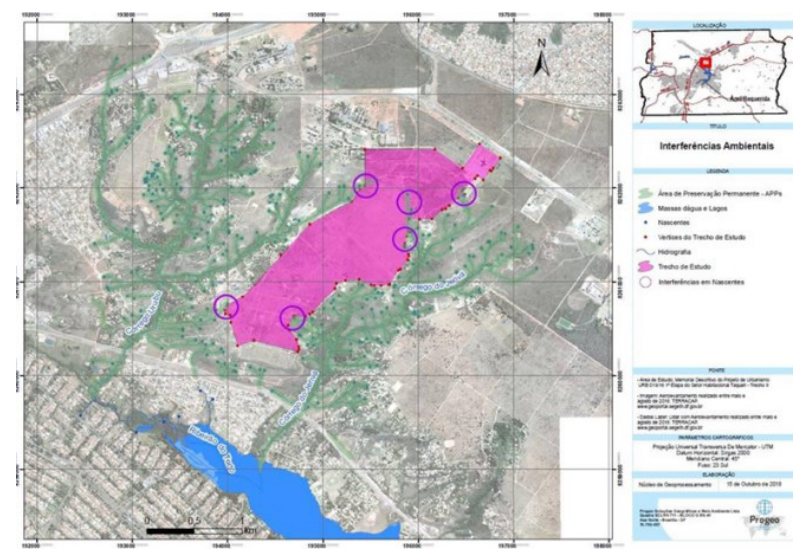

Figura 14: A Poligonal do Trecho 2 da Etapa 1 do SHTQ sobre o mapa de Áreas de Preservação Permanente do DF.

Fonte: PROGEO, 2018

Importante ressaltar que as Áreas de Preservação Permanente são definidas no Código Florestal, Lei 12.651/2012, como áreas com função ambiental de preservar os recursos hídricos, a paisagem, a estabilidade geológica, a biodiversidade, facilitar o fluxo gênico de fauna e flora, proteger o solo e assegurar o bem estar das populações humanas.

Dentre as APP determinadas no código florestal estão as calhas do leito regular dos rios em largura mínima de 30 metros. Estas regiões somente poderão ter ocupação urbana em caso de utilidade pública, interesse social ou baixo impacto ambiental, caso contrário, o proprietário destas áreas tem o dever de preservá-las com sua vegetação nativa. Este seria o caso da TERRACAP com relação às áreas de grande sensibilidade ambiental como é o caso do Trecho 2 da Etapa 1 do SHTQ.

No entanto, a análise crítica da proposta de ocupação deste espaço, mostra a evidência de um desprezo à eminência de impactos sobre uma área que é de grande vulnerabilidade ambiental, recarga do Lago Paranoá, em um contexto de crise hídrica (ANDRADE et al, 2018). A análise da caracterização do local e dos mapas que demonstram a sensibilidade ambiental da região, remete a uma destituição do papel de efetividade nas diretrizes relacionadas à responsabilidade ambiental, recuperação de áreas degradadas e preservação do ecossistema do cerrado.

\subsection{Análise dos Projetos de Urbanismo e de Drenagem para o Trecho 2 da Etapa 1}

No presente artigo, o objeto de estudo é o projeto de urbanização, Figura 15, incluído o projeto de drenagem, Figura 16, para o Trecho 2 da Etapa 1 do SHTQ, elaborado pela TERRACAP em 1999 e revisado em 2016. A TERRACAP - Agência de Desenvolvimento do Distrito Federal, é vinculada ao Governo do Distrito Federal, tem como finalidade subsidiar políticas públicas que visem ao crescimento econômico e social em Brasília.

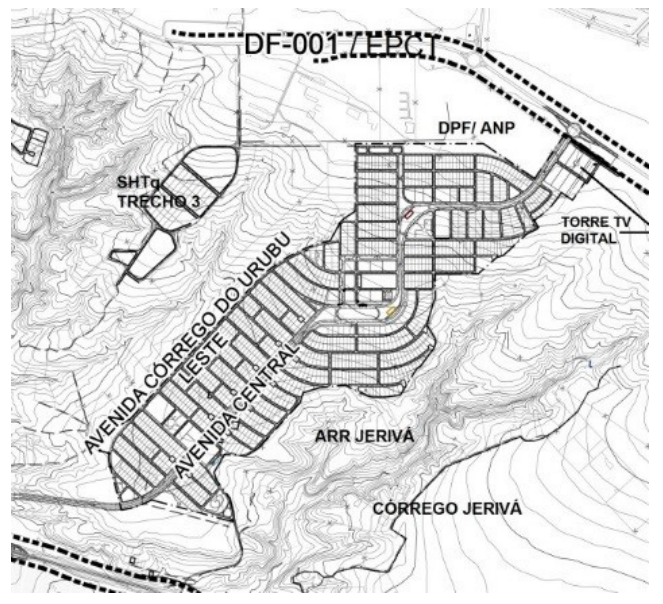

Figura 15: Projeto de Urbanização para o Trecho 2 da Etapa 1 do SHTQ. Fonte: TERRACAP, 2016.

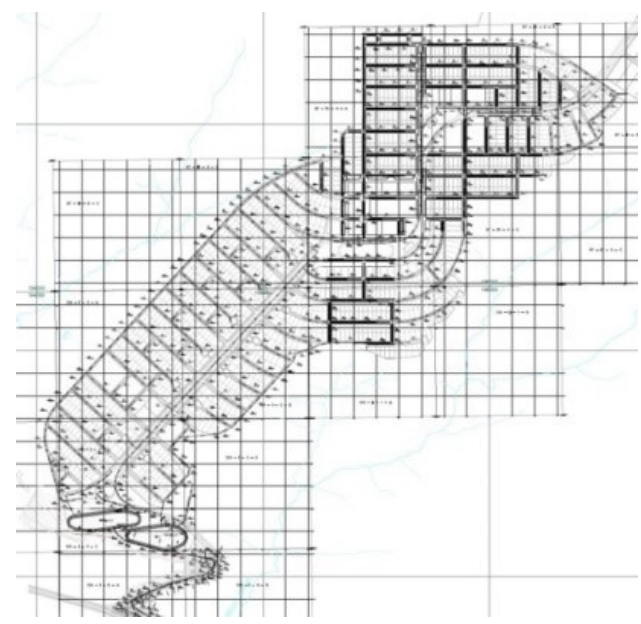

Figura 16: Projeto de Drenagem para o Trecho 2 da Etapa 1 do SHTQ. Fonte: TERRACAP, 2016 


\begin{tabular}{|c|c|}
\hline MDE 111/99 & NOTAS/DIRETRIZES/OPORTUNIDADES (ANDRADE, 2014) \\
\hline $\begin{array}{l}\text { O setor localiza-se dentro da poligonal da Área de } \\
\text { Proteção Ambiental do Lago Paranoá que tem entre } \\
\text { seus objetivos a recuperação e proteção qualitativa e } \\
\text { quantitativa dos recursos hídricos existentes na bacia, } \\
\text { de modo a promover redução do assoreamento e dos } \\
\text { níveis de poluição do Lago Paranoá. (Parte A, Fl. 3) }\end{array}$ & $\begin{array}{l}\text { Para evitar o assoreamento é imprescindível a manutenção da cober- } \\
\text { tura vegetal. Preservação da mata ciliar e revegetação com plantas } \\
\text { nativas do cerrado para aumentar a infiltração das águas. Uso de ca- } \\
\text { nais de escoamento e dispositivos que desloquem o fluxo da água } \\
\text { para lugares de solo permeável a fim de permitir a recarga. }\end{array}$ \\
\hline $\begin{array}{l}\text { (...) assegurando um padrão urbanístico adequado às } \\
\text { normas vigentes e preservando o meio ambiente em } \\
\text { seus aspectos essenciais foi o que o Governo priorizou } \\
\text { para evitar problemas ambientais advindos de uma ocu- } \\
\text { pação desordenada em área de localização estratégica } \\
\text { com vista privilegiada, alta acessibilidade. (Parte B, Fl.1) }\end{array}$ & $\begin{array}{l}\text { A drenagem urbana depende em primeiro lugar do desenho urbano integrado } \\
\text { aos elementos paisagísticos tanto naturais quanto planejados, forma de distri- } \\
\text { buição e densidade de edificações, escoamento e segurança da água, proteção } \\
\text { contra cheias, saúde ecológica das paisagens terrestre e aquática, pavimen- } \\
\text { tação, vegetação, encontros sociais no espaço para o bem estar social etc. }\end{array}$ \\
\hline $\begin{array}{l}\text { A área possui vocação hidrogeológica elevada para } \\
\text { os padrões estabelecidos no DF, mas extremamen- } \\
\text { te sensível às modificações ambientais. Fl. } 3\end{array}$ & $\begin{array}{l}\text { A interface solo/vegetação/atmosfera tem forte influência no ciclo hidrológico, nes- } \\
\text { se sentido mudanças no uso do solo terão consequências climáticas que vão afetar } \\
\text { o regime hídrico das bacias hidrográficas, alterar limites de várzea, forma e tama- } \\
\text { nho do leito e margens dos córregos, prejudicando todo o ecossistema aquático }\end{array}$ \\
\hline $\begin{array}{l}\text { NOVACAP - Os locais de lançamento de águas } \\
\text { pluviais deverão ser licenciados pelo IEMA/ } \\
\text { SEMATEC. (Parte B, FI. 4) }\end{array}$ & $\begin{array}{l}\text { O Desenho Urbano sensível à água busca a infiltração da água em pri- } \\
\text { meiro lugar, não o escoamento. É preciso permitir a absorção da } \\
\text { água da chuva em excesso e proteger contra alagamentos. }\end{array}$ \\
\hline $\begin{array}{l}\text { CAESB - ÁGUA - Aprova as alternativas elencadas } \\
\text { como proposta para utilização, no entanto, ressalta } \\
\text { a necessidade de utilização do ribeirão Bananal para } \\
\text { complementação do sistema. (Parte B, Fl. 4) }\end{array}$ & $\begin{array}{l}\text { Considerar a infiltração da água em nível macro, quem vai } \\
\text { produzir água são as raízes das árvores a partir da infiltra- } \\
\text { ção das águas das chuvas e não o Ribeirão Bananal. }\end{array}$ \\
\hline $\begin{array}{l}\text { A estruturação de um eixo viário que corta a gleba no } \\
\text { sentido Norte/Sul, assumindo a sinuosidade carac- } \\
\text { terística do relevo. (Parte B, Fl. 8) }\end{array}$ & $\begin{array}{l}\text { As vias desempenham papel fundamental na drenagem urbana. A água sem- } \\
\text { pre procura o sentido da maior declividade, ou seja, perpendicular à curva de } \\
\text { nível. A via principal projetada corta o Setor no sentido transversal às curvas de } \\
\text { nível sendo necessário prever meios de evitar a velocidade excessiva do esco- } \\
\text { amento das águas pluviais, tal como o uso de Biovaletas ao longo das vias. }\end{array}$ \\
\hline
\end{tabular}

Tabela 3: Cenários de Análise Trecho 2 da Etapa 1 do SHTQ. Fonte: Conserva, 2018.

Na Tabela 3, uma síntese da análise do MDE-111/99 (GDF, 1999), relativo ao projeto urbanístico do Trecho 2 Etapa 1 do SHTQ, nos aspectos relativos à drenagem analisados em função dos padrões de ANDRADE (2014).

$O$ projeto urbanístico para a área de estudo se insere em um modo tradicional de pensar a drenagem urbana (ANDRADE et al, 2018). A análise crítica começa quando se percebe que o projeto de drenagem elaborado pelo poder público para o Trecho 2 Etapa 1 do SHTQ tem conceito fortemente centrado no sistema convencional, composto por dispositivos coletores e de transporte das águas superficiais. A Tabela 4 apresenta uma síntese da análise do projeto de drenagem para o Trecho 2 da Etapa 1 do SHTQ elaborado pela TERRACAP, face aos padrões de ANDRADE (2014).

\begin{tabular}{|l|l|}
\hline $\begin{array}{c}\text { PROJETO DE DRENAGEM } \\
\text { Trecho } 2 \text { Etapa } 1 \text { SHTQ }\end{array}$ & \multicolumn{1}{c|}{$\begin{array}{c}\text { NOTAS/DIRETRIZES/ } \\
\text { OPORTUNIDADES }\end{array}$} \\
\hline $\begin{array}{l}\text { O projeto tem como particu- } \\
\text { laridade a presença de duas } \\
\text { bacias de detenção na parte } \\
\begin{array}{l}\text { Sul da poligonal, nas pro- } \\
\text { ximidades DF-005 - EPCT. }\end{array}\end{array}$ & $\begin{array}{l}\text { Bacias de detenção não favo- } \\
\text { recem a infiltração das águas, } \\
\text { um dos principais aspectos do } \\
\text { Necessidade de preservação dos } \\
\text { cursos d'água através da perse- } \\
\text { guição da absorção das águas, } \\
\text { garantindo a recarga dos aquíferos. }\end{array}$ \\
\hline $\begin{array}{l}\text { O local das bacias de } \\
\text { detenção tem relevo consi- } \\
\text { deravelmente acidentado, } \\
\text { com alta declividade. }\end{array}$ & $\begin{array}{l}\text { O local tem limitações a respeito } \\
\text { da estabilidade do talude natural, a } \\
\text { resistência do solo, considerando a } \\
\text { mudança de geometria, o sobrepe- } \\
\text { so e a percolação das águas no solo. }\end{array}$ \\
\hline $\begin{array}{l}\text { O projeto das Bacias indica } \\
\text { lançamento das galerias } \\
\text { no Lago Paranoá. }\end{array}$ & $\begin{array}{l}\text { O lançamento dessas águas residu- } \\
\text { ais no Lago Paranoá é incompatível } \\
\text { com a realidade crítica atual de } \\
\text { escassez e a necessidade de preser- } \\
\text { vação da qualidade das suas águas }\end{array}$ \\
\hline
\end{tabular}

Tabela 4: Análise do Projeto de Drenagem Trecho 2 da Etapa 1 do SHTQ Fonte: 0 s autores. 
De acordo com a análise de Carvalho (2018), o projeto tem $86 \%$ de impermeabilização por lotes e vias, com uma rede de drenagem projetada prevendo 525 condutos, 524 PVs, 491 áreas de contribuição e 2 bacias de detenção ao final da rede. Levando em consideração o volume que deixará de infiltrar na superfície pela falta de alimentação do lençol freático, o volume de águas escoadas tende a aumentar em várias ordens de magnitude.

A abordagem tradicional, ainda utilizada pelo urbanismo neoliberal para o manejo das águas urbanas tem contribuído para aumentar os prejuízos financeiros, ambientais, estéticos, à saúde e, sobretudo, à qualidade de vida da população (ANDRADE et al, 2018). O lançamento das águas residuais no Lago Paranoá é incompatível com a realidade crítica atual de escassez, uma vez que pode esgotar sua capacidade de depuração, além de ter se tornado manancial destinado a colaborar para evitar o desabastecimento, com suas águas agora destinadas ao consumo humano.

O parcelamento como proposto trará mudanças no uso do solo que incidem mudanças climáticas e afetam o regime hídrico das bacias hidrográficas, pois alteram limites de várzea, a forma e o tamanho do leito e margens dos córregos, afetando diretamente a circulação local da água, os processos de infiltração, escoamento e todos os ecossistemas aquáticos. (ANDRADE et al, 2018). O desafio ignorado é a conciliação da densidade populacional aos padrões de ocupação e uso do solo à justiça socioambiental, capacidade de suporte das cidades mediante a pegada ecológica e à dinâmica da água urbana.

Segundo as ponderações do MPDF o projeto de parcelamento do solo do Trecho 2, apesar de registrado em cartório, requer estudo ambientais prévios e licenças (ambiental e urbanística), bem como projetos adequados de paisagismo, drenagem e esgoto (ANDRADE et al, 2018).

Nota-se que o projeto proposto apresenta ausência completa de infraestrutura Socioecológica de sensibilidade às águas. Apesar de possuir licenças ambientais e urbanísticas, requerem maneiras de ocupação do território que causem menos impactos ao meio ambiente e que não prejudiquem a produção das águas atualmente produzidas pelas raízes da vegetação preservada, com o uso de um aporte de infraestrutura com sensibilidade aos fluxos das águas.

\subsection{Oportunidades de Desenho Urbano Sensível à Água na Serrinha do Paranoá}

O desenho urbano sensível à água considera os fluxos das águas desde os primeiros traços do projeto urbanístico, determinando em muitos aspectos, o desempenho da drenagem, somando os efeitos da densidade das ocupações urbanas no escoamento superficial (ANDRADE et al, 2018). A Infraestrutura Socioecológica, com a visão sistêmica, aponta para a necessidade de que o controle de velocidade das águas seja feito, em primeiro lugar e principalmente, no local onde caem as chuvas. Também na maneira como eles são desenhados, de forma que o desenho urbano favoreça a infiltração das águas o máximo possível e que somente após essa infiltração, recorra-se a medidas de escoamento.

O desenho urbano sensível à água, na abordagem da Infraestrutura Socioecológica coloca ênfase no desenho inclusivo, com uma drenagem em que a infiltração das águas está em primeiro lugar, prevendo vegetação abundante e canais de infiltração, permitindo a absorção do excesso de água da chuva e protegendo contra alagamentos.

Assim, com uma readequação do projeto existente é possível desenvolver um desenho mais ecológico e inclusivo no Trecho 2 da Etapa 1 do SHTQ com possibilidades efetivas de mitigação dos impactos eminentes, do enfrentamento da crise hídrica e ao atendimento à função social da propriedade (ANDRADE et al, 2018). Entre os movimentos comunitários locais e a própria Administração Regional do Lago Norte há consenso de que a área tem vocação para ser totalmente preservada e, caso a ocupação seja inevitável, que seja com uma forma ecologicamente sustentável.

Sobre estes aspectos, o projeto de pesquisa "Brasília Sensível à Água" (GDF, 2018) do Grupo de Pesquisa "Água e Ambiente Construído" da FAU/UnB, a pedido da promotoria do MPDFT, apresentou um desenho conceitual, Figura 17, com aplicação da Infraestrutura Socioecológica com biovaletas.

As biovaletas são canais abertos, cobertos por vegetação, que atenuam o escoamento das águas. Esse tipo de drenagem aumenta o contato direto da água com o solo utilizando a vegetação para filtrar (ANDRADE, 2014). As biovaletas reduzem o escoamento superficial, favorecendo a mitigação dos impactos ambientais e dos problemas causados pelas alterações causadas pela expansão urbana.

Aumento da Vazão Máxima pela Urbanização no Trecho 2 da Etapa 1 do SHTQ

Uma das formas de quantificar a parcela de chuva que escoa superficialmente é a multiplicação da precipitação por um coeficiente, o chamado coeficiente de "run off" ou coeficiente de escoamento superficial (C) pelo método 


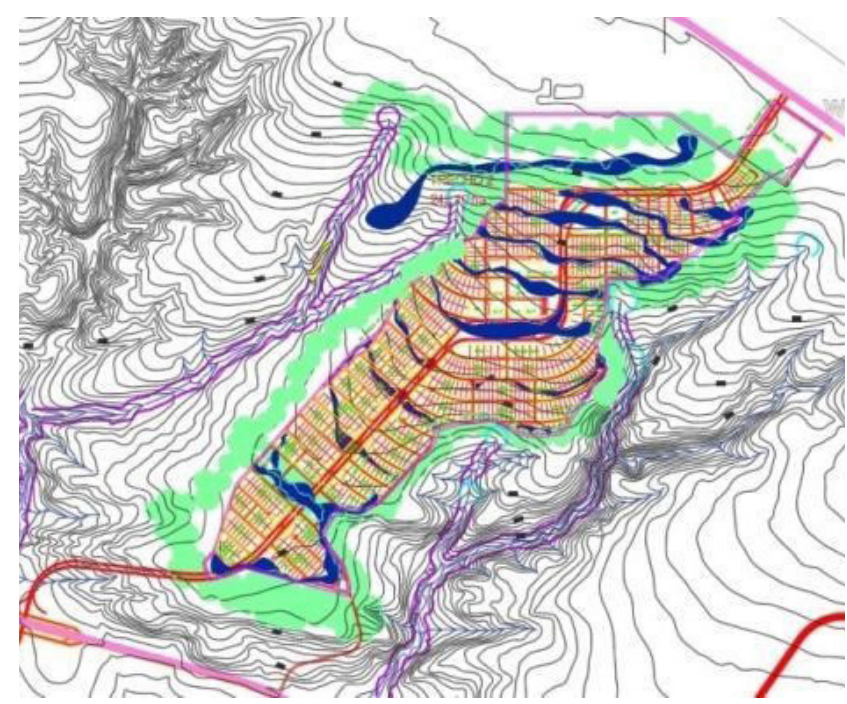

Figura 17: Desenho Conceitual Biovaletas Trecho 2 Etapa 1 SHTQ. Fonte: Brasília Sensível à Água, 2018

racional (ADASA, 2018). Por meio deste coeficiente determina-se a vazão máxima de projeto $(Q)$, Equações (1) a (3) de forma a medir como a urbanização interfere no ciclo hidrológico da bacia.

A determinação da vazão máxima $(\mathrm{Q})$ pelo método racional faz uso de uma simplificação que relaciona a vazão escoada com a intensidade da chuva precipitada sobre a área de drenagem (I), descontadas todas as perdas associadas com os demais processos do ciclo hidrológico, como a interceptação vegetal e a infiltração. A Resolução ADASA 9/2011 admite o uso do Método Racional para bacias de até 200 ha, com o uso da equação tradicional para vazão de pico:

Sendo: Q - Vazão Máxima de Escoamento; C - Coeficiente de Escoamento; A - Área do empreendimento. I - Intensidade da chuva dada pela Curva IDF de Brasília (ADASA, 2018):

$$
I=\frac{1.574,70 * T^{0,207}}{(t c+11)^{0,884}}
$$

$\mathrm{S}$ e $\mathrm{n}$ d o :

I=Intensidade em $\mathrm{mm} / \mathrm{h} ; \mathrm{T}=$ Tempo de Retorno em anos, tc = Tempo de Concentração em minutos, dado pela Fórmula (MIGUEZ et al, 2016):

$$
t c=57 *\left(\frac{L^{3}}{\Delta h}\right)^{0,385}
$$

Sendo: tc $=$ tempo de concentração em minutos;
$\mathrm{L}=$ Comprimento da bacia em $\mathrm{km} ; \Delta \mathrm{h}=$ Diferença de altitude ao longo da bacia em $\mathrm{m}$.

A tabela 5 aponta dados de Entrada para uso das equações 1 a 3 no cálculo simplificado para o Trecho 2 Etapa 1 SHTQ:

\begin{tabular}{|l|l|l|}
\hline \multicolumn{2}{|c|}{ Variável } & \multicolumn{1}{c|}{ Valores Adotados } \\
\hline C & Coeficiente de Escoamento & $\begin{array}{l}\text { Cenário 1: 0,15; Cenário 2: } \\
0,4 ; \text { (NOVACAP, 2012) }\end{array}$ \\
\hline A & Área de contribuição (ha) & 166 (Google Earth, 2018) \\
\hline T & Tempo de Retorno (anos) & 10 (ADASA, 2018) \\
\hline L & Comprimento da Bacia (km) & 3.422 (Google Earth, 2018) \\
\hline$\Delta \mathrm{h}$ & $\begin{array}{l}\text { Diferença de altitude } \\
\text { ao longo da Bacia (m) }\end{array}$ & (Google Earth, 2018) \\
\hline
\end{tabular}

Tabela 5: Dados de Entrada Trecho 2 da Etapa 1 do SHTQ. Fonte: Conserva, 2019

Apesar de a área da poligonal definida pela TERRACAP seja de 223 ha, consideramos 166 ha para os cálculos após desconstituídos os lotes na parte norte da poligonal, por constituíres terras adjacentes à Polícia Federal.

\section{RESULTADOS E DISCUSSÕES}

Para a vazão de cenários pré-desenvolvimento, cenário 1, a ADASA (2018) adotou um coeficiente de escoamento superficial de 0,15, com uma vazão máxima tolerável de 24,4 I/s/ha.

\begin{tabular}{|l|l|}
\hline \multicolumn{1}{|c|}{ Uso do Solo } & \multicolumn{1}{|c|}{$\begin{array}{c}\text { Coeficiente de } \\
\text { Escoamento (C) }\end{array}$} \\
\hline Áreas calçadas ou impermeabilizadas & 0,90 \\
\hline $\begin{array}{l}\text { Áreas intensamente urbaniza- } \\
\text { das e sem áreas verdes }\end{array}$ & 0,70 \\
\hline Áreas residenciais com áreas ajardinadas & 0,40 \\
\hline Áreas integralmente ajardinadas & 0,15 \\
\hline
\end{tabular}

Tabela 6: Valores para Coeficiente de Escoamento. Fonte: NOVACAP, 2012

Em conformidade com a Figura 18, o Coeficiente de Escoamento adotado para o Cenário 1 foi 0,15 (NOVACAP, 2012). Para a proposta de projeto como apresentada pela Administração Pública, cenário 2, adotou-se 0,4. Aplicando-se os dados da Tabela 4 às Equações (1), (2) e (3), resulta um aumento da vazão máxima, pelo Método Racional, de $167 \%$.

Carvalho (2018) por sua vez, faz uma análise na qual 
simula os três cenários, mas com modelagem SWMM em interface PCSWMM com o método SCS, que calcula a geração do escoamento superficial por meio de um coeficiente CN - "curve number", para análise da infiltração e do escoamento superficial. Foi utilizada a modelagem hidrodinâmica que calcula a vazão em cada poço de visita somando as entradas dos volumes de água em cada poço ao longo da rede.

O SCS é um método amplamente utilizado para estimar o escoamento de eventos de chuva. Ele foi adaptado para muitas partes do mundo e aplicado com sucesso em cálculos de alterações de escoamento a partir de mudanças no uso do solo (MUCHE, 2019). É um método empírico comum que estima o escoamento superficial de eventos de precipitação na escala da bacia hidrográfica. Integra Influências hidrológicas combinadas do tipo de solo, uso da terra, manejo da terra, condição hidrológica e condição de umidade antecedente. O método CN foi adaptado para áreas com uso de terra variável com cobertura e condições climáticas em muitas partes do mundo, e aplicado em cálculos de escoamento e avaliação da mudança do uso da terra.

A simulação por Carvalho (2018) demonstrou que as biovaletas não encheram até a altura máxima estipulada no projeto conceitual: 1 metro. Com período de retorno de 10 anos, a maior lâmina de água na superfície das biovaletas foi da altura de $33,6 \mathrm{~cm}$ em seu momento de maior cheia. A média de altura da lâmina d'água dentro das valas (considerando todas as subdivisões) foi de $17,7 \mathrm{~cm}$. Com uma chuva de projeto para Tempo de Retorno de 10 anos e simulação de base contínua, o aumento da vazão máxima do cenário 1 para o cenário 2 foi de 98\% (CARVALHO, 2018). Percebe-se que a geração do escoamento superficial foi quase o dobro, considerando o projeto a ser implantado. Já na simulação do cenário 3 foi encontrado valor referente a uma diminuição na vazão máxima de lançamento com relação ao cenário 2 de até 97\% (CARVALHO, 2018). Ou seja, a urbanização com biovaletas pode acontecer com alteração mínima nas parcelas do ciclo hidrológico, Tabela 7.

\begin{tabular}{|l|l|l|}
\hline & $\begin{array}{l}\text { Cenário 1 para } \\
\text { o Cenário 2 }\end{array}$ & $\begin{array}{l}\text { Cenário 2 para } \\
\text { o Cenário 3 }\end{array}$ \\
\hline Método Racional (\%) & 167 & \\
\hline SWMM (\%) & 98 & $-91,85$ \\
\hline
\end{tabular}

Tabela 7: Variação na Vazão Máxima entre Cenários.

Fonte: Conserva, 2019.
A análise destes resultados significa, pela abordagem Socioecológica, que a ação do homem ao ocupar o espaço, nos moldes do projeto da Administração Pública, vai implicar em maiores volumes de águas escorrendo, com maior vazão e maiores velocidades. Porém, em um aparente paradoxo, tais águas, ao chegarem ao Lago Paranoá em vez de aumentar, diminuem a disponibilidade hídrica, uma vez que o aumento da vazão contribui para a formação de erosões e assoreamentos, com todas as consequências para um contexto que já é de crise hídrica.

A figura 19 demonstra as parcelas do ciclo hidrológico
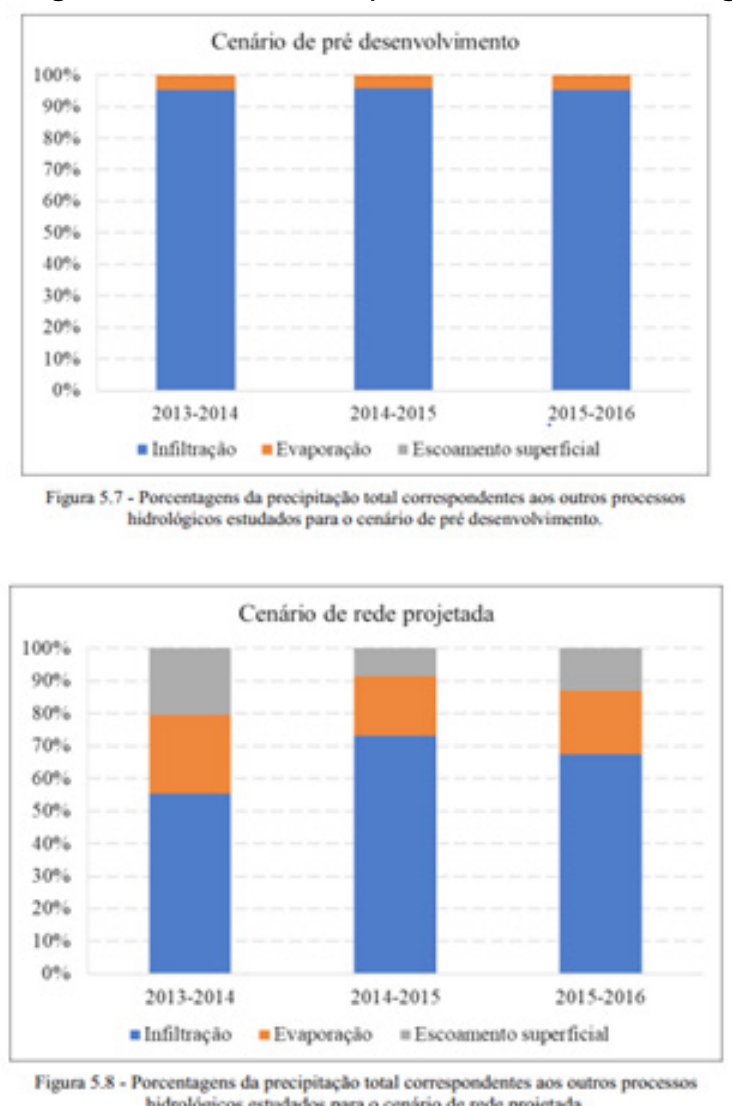
hidrológicos estudados para o cenário de rede projetade.

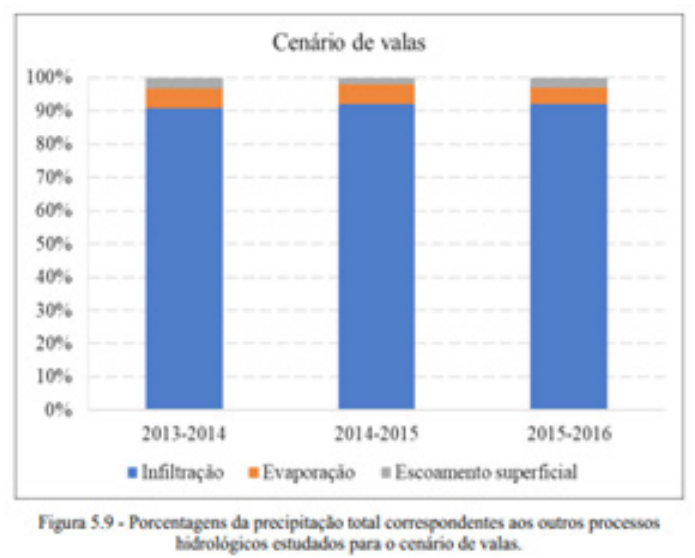

Figura 19 - Gráficos representativos da simulação SWMM Trecho 2 Etapa 1 SHTQ. Fonte: Carvalho, 2018. 
para cada um dos três cenários, simulados no SWMM por Carvalho (2018).

No cenário 1, pré-desenvolvimento, o predomínio da infiltração, com pouca geração de escoamento superficial. No cenário 2 devido à alteração do uso e ocupação do solo, o escoamento superficial e a evaporação tornam-se parcelas consideráveis, reduzindo a infiltração no local, comprometendo as nascentes na região. O cenário 3, ocupação urbana mais Infraestrutura Socioecológica com uso de biovaletas, indica uma urbanização menos impactante com alterações mínimas no ciclo hidrológico.

$\mathrm{Na}$ análise no balanço hídrico, percebe-se que a rede proposta altera bastante o ciclo, mesmo com a implantação das bacias de detenção, uma vez que estas estruturas não favorecem a infiltração. Com a implantação das proposições da infraestrutura Socioecológica, como as biovaletas, haverá maior aproximação com o cenário de pré-desenvolvimento, que é aquele no qual a região do Trecho 2 da Etapa 1 SHTQ se encontra hoje.

\section{CONSIDERAÇÕES FINAIS}

As técnicas de drenagem urbana convencional não abordam o problema do ponto de vista do ciclo hidrológico, resolvendo apenas o problema imediato de escoamento amento superficial e da vazão máxima alerta para um cenário em que se transfere o excesso de precipitação para jusante através das galerias, podendo prejudicar a recarga do Lago Paranoá, em uma inadequação à realidade de escassez hídrica pela qual passa Brasília no momento da escrita.

Tal cenário motiva a busca por padrões de ocupação do território que sejam sensíveis á água, ao tempo em que se busquem métodos mais eficientes na elaboração de projetos de drenagem urbana, que mitiguem os impactos ambientais ocasionados pelo processo de urbanização: a drenagem projetada com bases nos padrões da Infraestrutura Socioecológica.

Um dos grandes desafios para os planejadores do espaço urbano está em conciliar, de forma sistêmica, o uso dos recursos da terra de forma a garantir um futuro sem escassez de água potável no planeta. A aplicação do estudo dos padrões dos ecossistemas urbanos de ANDRADE (2014) no estudo do caso do SHTQ torna-se importante por verificar, na prática, como lidar com um tipo de desenho que favorece a disponibilidade hídrica.

A partir da análise da caracterização do local da pesquisa e do aumento da vazão máxima, observa-se que a implantação do empreendimento pode não justificar os

impactos naturais eminentes ao local e à escala metropolitana de Brasília.

A pesquisa evidencia que é possível sim haver um desenho urbano sensível ao ciclo urbano da água. Por se tratar de área com grandes declives em direção ao Lago Paranoá, é preciso pensar a drenagem pela diminuição da velocidade e vazão das águas ao longo do traçado das vias, com o uso, por exemplo, das biovaletas, bem como na revisão do desenho do empreendimento na visão do todo. Tudo isso para que as águas pluviais não cheguem ao Lago Paranoá com maior vazão, garantindo níveis de qualidade das águas e mitigação dos prejuízos advindos da urbanização da área, caso essa urbanização, naquele local, ainda que sensível ambientalmente, seja inevitável.

\section{REFERÊNCIAS}

ADASA, Agência Reguladora de águas, Energia e Saneamento do Distrito Federal. Manual de Drenagem e Manejo de Águas Pluviais Urbanas do Distrito Federal. Brasília: UNESCO. 2018. 319p.

\section{ANDRADE, L. (2014). Conexões dos Padrões} Espaciais dos Ecossistemas Urbanos: A Construção de um Método com Enfoque Transdisciplinar para o Processo de Desenho Urbano Sensível à Água no Nível da Comunidade e da Paisagem. 2014. 544 f., il. Tese (Doutorado em Arquitetura e Urbanismo)Universidade de Brasília, Brasília, 2014.

ANDRADE, Liza Maria Souza; LACERDA, Guilherme. Nery; OLIVEIRA, Adriane Balieiro; OLIVEIRA, Alessandra Adriane Barbosa; DANTAS, André Luiz Faria.; CAMARGO, Pedro Rodolpho Ramos Camargo (2016). Brasília Sensível à Água. Anais. Artigo. IV ENANPARQ. Porto Alegre. 20 p.

ANDRADE, L. M. S.; CONSERVA, C. S.; LEMOS, N. S.; PRATESS.C.; NOBREGA, G.D.P.Gestão Compartilhada para Cidades Sensíveis à Água: O Agenciamento de Atores para o Fortalecimento do Lago Paranoá e o Enfrentamento da Crise Hídrica em Brasília. Artigo. PLURIS. Porto Alegre, 2018. 12 p.

ANDRADE, L. M. S. ; LEMOS, NATÁLIA S. ; CONSERVA, C. S. ; SOUTO, B. M.;OLIVEIRA, E. M.; Urbanismo Neoliberal e a Escassez de Água: A Importância do Desenho Urbano Sensível à Água inclusivo na Serrinha do Paranoá na Bacia do Paranoá. Seminário Internacional Urbanismo Biopolítico. Artigo. Belo Horizonte, 2018. 18 p. 
BENEVOLO, L. História da Cidade. São Paulo. Perspectiva, 2011.

BRASÍLIA REVISITADA. Anexo 1 do Decreto $\mathrm{n}^{\circ}$ 10.829/1987 - GDF e da Portaria no 314/1992 - Iphan. 1986.

BUSCHBACHER, R. A Teoria da Resiliência e os Sistemas Socioecológicos: como se preparar para um futuro imprevisível? Boletim Regional, Urbano e Ambiental, v. 9, p. 11-24, 2014.

CARVALHO, D.J. Manejo de Águas Pluviais Urbanas com Solução de Baixo Impacto em Área Residencial. Estudo de Caso: Setor Habitacional Taquari Etapa 1 Trecho 2. Trabalho de Conclusão de Curso de Graduação. Engenharia Ambiental. Universidade de Brasília, 2018. 89 p.

CODEPLAN, Relatório do Plano Piloto de Brasília. Brasília: Arquivo Público do Distrito Federal. 1991.

CONSERVA, C. S.; ANDRADE, L.M.S; SANT'ANA, D. R.; COSTA, M. E . L.; CARVALHO, D. J. Olhares sobre a Drenagem em Brasília: Expansão do Território e Infraestrutura Socioecológica na Serrinha do Paranoá, DF. Artigo ENSUS - VII Encontro de Sustentabilidade em Projeto, 2019.

FLETCHER. T. D.; SHUSTER, W.; HUNT W. F.; ASHLEY R.; BUTLER D.; ARTHUR, S.; TROWSDALE $S_{\text {; }}$ BARRAUD S.; SEMADEMI-DAVIES, BERTRAND-KRAJEWSKI. JeanLUC, MIKKELSEN P. S.; RIVARD G.; UHL M.; DAGENAIS D.; VIKLANDER M.; SUDS, LID, BMPs, WSUD and More - The Evolution and Application of Terminology Surrounding Urban Drainage. Urban Water Journal. 2015.

GDF - Governo do Distrito Federal. Memorial Descritivo MDE 111/99 Lago Norte RA XVIII SHTQ, Setor Habitacional Taquari Trecho 2. TERRACAP Companhia Imobiliária de Brasília. 1999.

GDF - Governo do Distrito Federal. Projeto Brasília sensível à água para aplicação piloto na expansão urbana da Serrinha do Paranoá sob a ótica dos padrões da infraestrutura ecológica integrados aos padrões de inclusão social a partir de Soluções baseadas na Natureza.
Edital 03/2018 - Seleção Pública de Propostas de Pesquisa Científica, Tecnológica e Inovação, Demanda Espontânea. FAP - Fundação de Apoio a Pesquisa do Distrito Federal, 2018.

HERZOG, C. Infraestrutura Verde para Cidades Mais Sustentáveis. ICLEl, 2010.

KOIDE, S. Quantificação de Parâmetros Hidrológicos em Campo. ReCESA, 2008.

MIGUEZ, M., VEROL, A., \& REZENDE, O.; Drenagem Urbana: do Projeto Tradicional à Sustentabilidade. Rio de Janeiro: Elsevier. 2016.

NOVACAP. Companhia Urbanizadora da Nova Capital. Termo de referência e especificações para elaboração de projetos de sistemas de drenagem pluvial no Distrito Federal. 2012.

PELLEGRINO, P; MOURA, N. B.; Estratégias para uma Infraestrutura Verde. Barueri, SP. 2017.

ROSSMAN, L. A.; SWMM 5.0 Manual do Usuário. Water Supply and Water Resources Division National Risk Management Research Laboratory. Cincinnati, 2010.

SEGETH - Secretaria de Estado de Gestão do Território e Habitação. GEOPORTAL, 2018. Disponível em https:// www.geoportal.segeth.df.gov.br/mapa/\#, consultado em 18 de novembro de 2018.

WWDR. World Water Development Report. Nature Based Solutions for Water. UNESCO, 2018. 


\section{AUTORES}

ORCID: https://orcid.org/0000-0003-3955-4775

CÁtIA DOS SANTOS CONSERVA | Universidade de Brasília, Programa de Pós-Graduação em Arquitetura e Urbanismo, Universidade de Brasília, Faculdade de Arquitetura e Urbanismo. | Instituto Central de Ciências - ICC Norte Gleba A, Asa Norte, 70904-970 - Brasilia, DF - Brasil

ORCID: https://orcid.org/0000-0002-6624-4628

LIZA MARIA SOUSA DE ANDRADE, Dra. | Universidade de Brasília, Programa de Pós-Graduação em Arquitetura e Urbanismo, Universidade de Brasília, Faculdade de Arquitetura e Urbanismo. | Instituto Central de Ciências - ICC Norte Gleba A, Asa Norte | 70904-970 - Brasilia, DF - Brasil

ORCID: https://orcid.org/0000-0002-9020-081X

DANIEL RICHARD SANT'ANA, Dr. | Universidade de Brasília, Programa de Pós-Graduação em Arquitetura e Urbanismo, Universidade de Brasília, Faculdade de Arquitetura e Urbanismo. | Instituto Central de Ciências - ICC Norte Gleba A, Asa Norte, 70904-970 - Brasilia, DF - Brasil

ORCID: https://orcid.org/0000-0002-9401-5777

DANIELA JUNQUEIRA CARVALHO | Universidade de Brasília, Faculdade de Tecnologia, Departamento de Engenharia Civil e Ambiental. SG - 12, PTARH. |Campus Universitário Darcy Ribeiro, Asa Norte, 70910900 - Brasília, DF - Brasil

ORCID: https://orcid.org/0000-0002-5477-4349

MARIA ELISA LEITE COSTA, M.Sc. | Universidade de Brasília, Faculdade de Tecnologia, Departamento de Engenharia Civil e Ambiental. SG - 12, PTARH. | Campus Universitário Darcy Ribeiro, Asa Norte, 70910900 - Brasília, DF - Brasil

\section{COMO CITAR ESTE ARTIGO}

CONSERVA, Cátia dos Santos; ANDRADE, Liza Maria Sousa de; SANT'ANA, Daniel Richard; CARVALHO, Daniela Junqueira; COSTA, Maria Elisa Leite. Olhares sobre a Drenagem em Brasília: Expansão Urbana e Infraestrutura Socioecológica na Serrinha do Paranoá, DF. MIX Sustentável, [S.I.], v. 5, n. 2, p. 149-164, jun. 2019. ISSN 24473073. Disponível em:<http://www. nexos.ufsc.br/index.php/mixsustentavel>. Acesso em: dia mês. ano. doi:https://doi.org/10.29183/2447-3073. MIX2019.v5.n2.149-164.

DATA DE ENVIO: 22/04/2019

DATA DE ACEITE: 23/04/2019 